\title{
SUFISM AND MILLENNIAL GENERATION MOVEMENTS IN MODERN NUSANTARA
}

\author{
Elmansyah \\ Insitut Agama Islam Negeri (IAIN) Pontianak, Indonesia \\ E-mail: elmans@iainptk.ac.id \\ Saimi bin Bujang \\ Universiti Teknologi MARA, Sarawak, Malaysia \\ E-mail: Saimi496@sarawak.uitm.edu.my \\ Muhammed Sahrin bin Haji Masri \\ Universiti Islam Sultan Sharif Ali, Brunei Darussalam \\ E-mail: sahrin.masri@unissa.edu.bn
}

\begin{abstract}
This article aims to show how Sufism has survived and existed in the history of Nusantara Islamic civilization. This is interesting, especially for the millennial generation, as an example of dealing with the swift currents of change and the desire to build the Indonesian Islamic Civilization within Islam Nusantara context. The data of the work is based on a comparative research project with a historical approach. The work suggets four key findings. First, the emergence of Sufism in the 3rd century of Hijri was part of the response in changes in Islamic civilization. Second, to counter the unexpected changes in time, the Sufis returned to the spiritual teachings, so as to avoid negativity. Third, strong mentality of Sufis made them travel around the world to create a new civilization. Fourth, tolerant attitudes and models of the Sufis are the mainstay in achieving their mission.
\end{abstract}

Keywords: Sufism, Sufis, and Millennial, generation, movement, Islam, civilization

\section{INTRODUCTION}

Recently there has been a lot of talk about groups of young people who are making drastic changes in attitudes, behavior and dress styles/appearance. Women tend to be dressed in a closed fashion, with large headscarves and loose clothes, and many have even started wearing niqab sporting all-black. Men have begun to grow their beards and wear cingkrang pants (hanging above the ankle). In matters of worship, study, and memorization of the Qur'an, they are not inferior to young people who live in Islamic boarding schools. 
However, they do not leave the world of technology, or perhaps are even more sophisticated in this field, when compared to others. Internet and social media are the main connectors in communication, staying in touch and spreading knowledge within their group and with other groups. Other trendy terms among young people include "hijrah", "getting married young" and "syar'i".

It is not known for sure as to when this kind of movement started among young people in Indonesia. However, this movement has continued to grow carrying the Islamic symbols they observe. If viewed and read carefully, the phrases that appear on social media and the Internet, it begins to lead to the desire to establish the Islamic Sharia in Nusantara, especially in the case of Indonesia. General elections seem to be the right moment to voice their ideas and desires to the public. So it is natural when some people think that this is a serious threat to the integrity of the nation, because it seems as if they wanted to replace the Pancasila with Islamic Sharia as the basis of the state.

Furthermore, due to the influence of such a massive political campaign, various pessimistic expressions arose in overcoming the conditions of the nation. Hate speeches, written posts, short videos or multi-interpretational memes have made those who read or see them participate in a pessimistic stream. Even though based on statistical data, Indonesia will face what is called the Demographic Bonus, where the productive age will be far greater than the non-productive. Basically, this is just an ordinary issue in a society's dynamics. This all happens due to a rapid flow of information and transportation, where distance and time is becoming increasingly depleted. Technological sophistication that continues to grow, has become an important factor that causes these changes. Young people born between 1980 and 2000, who tend to be different from the previous generation, are often referred to as the millennial generation.

Millennial generation ${ }^{1}$ is a new generation of this century, which is characterized by their sophistication in operating digital technology ${ }^{2}$. This century is known as, the Age of the Intellect. Dr. Ganesh Shermon, has gathered several key terms: Easy to Deal, Speed, Flexibility, Character, Perpetuity, Freedom, Savvy, MultiTasking, Work Ethics, Know-How, Intelletual Arrogance, Socially Conscious, Change Friendly, Individual \& Team, I \& We, and Tech Dependent. These terms can be associated with the term Millennial. This is because those who are called the millennial generation understand technology better; they believe they can work flexibly, anytime and anywhere unlimited (Ganesh Shermon, 2017: 22).

${ }^{1}$ The term millennial in the English dictionary meansa period of 1000 years, especially calculated before or after the birth of Christ. (A. S. Hornby, 1995: 739).

${ }^{2}$ The word "digital" derives from "digit", meaningany of the ten numbers from 0 to 9 ; Numberof fingers, thumb or toes (A.S. Horby, 1995: 232). 
In fact, the termcoined by John Palfrey and Urs Gasser was "Digital Native". This generation is a generation born after the 1980s, when digital social technology was widely used. They all have extraordinary skills in utilizing and building these technology networks (John Palfrey \& Urs Gasser, 2008: 1).

The sophistication of digital technology, on the one hand brings positive values, but on the other hand has implications for negative values. The positive impact of digital technology obviously has brought tremendous benefits among mankind. Ease and speed of access to information provides comfort and pleasure in communicating and interacting with each other. However, on the other hand, it creates new issues which sometimes hit the aspects of morality which have been maintained and respected by the community such as pornography, gambling, online prostitution, an instant desire, and social autism (Elmansyah, 2016: 68).

In light of this reality, there are many things that should be done in order to build a millennial generation that is ready to exist in creating global civilization. The questions are what kind of civilization is desired? What preparation should be made? In this millennial era, it is clear that everything depends on the individual.The future must be created, not just going where the wind blows. Therefore, especially for Muslims, the civilization offered by Sufism, as exemplified by previous generations, can be used as a concrete example in dealing with developments in society. I would like to show the patterns of Sufi movements in building Muslim civilization. These patterns, I believe, will be able to provide encouragement for the millennial young generation, to defend them selves, as well as to exist and succeed in changing world. Mental and spiritual reinforcement is the key to building a strong Muslim civilization in the future.

\section{SUFI CIVILIZATION}

A civilization will be created through a struggle of thought which in turn gives birth to a product that improves mankind. In its history, there have been several major themes of thought that built Islamic civilization, namely: fiqh, kalam, philosophy and Sufism. Each of these major themes is basically the efforts of Muslim intellectuals in positioning the Qur'an and the Sunnah, in order to respond to the development of times in all fields of social life, law, politics, and science. In the time of the Abbasids, the imams of the four schools who succeeded in formulating positive law, the kalamscholarssuch as the Khawarij, MurjiahandMu'tazilah could speak in the political order, while the scholars who concentrated on the philosophy succeededin producinguseful works, for example in medical field (Elmansyah Al-Haramain, 2014: 9). 
Etymologically, the term "peradababan" in Indonesian is derived from the word "addaba" which in Arabic has quite a lot of meanings. Adab, if taken from the sentence, "ta addaba" means the same as "tahadzdzaba" which means, educated. A person who is educated will become "muaddiban", meaning civilized, polite or well-mannered. When combined with the word related to work, it means the rules of the game (as in the sentence: adab alSuluk, meaning the rules in suluk / behavior). There is another sentence that continues with the word adab, whose meaning becomes quite far, such as: Ilm al-Adab, which means: literary science (Ahmad Warson Munawwir, 1984: 13). Perhaps that is what makes the word " $a d a b$ " in Indonesian, interpreted as subtle character; good morals, language, and courtesy. Furthermore, when added the prefix pe and the suffix an, it means "civilization",and interpreted as advancement (intelligence, culture) physically and emotinally of a nation (Tim Penyusun, 2008: 9).

Terminologically, the term "peradaban" according to Badri Yatim in his book, History of Islamic Civilization, is a translation of an Arabic word that reads: al-hadharah, which means culture. While the word: culture itself is derived fromthe word: al-tsaqafah. Therefore, anthropologists distinguish the two terms, where civilization is reflected in politics, economics and technology; while culture is reflected in art, literature, religion and morals (Badri Yatim, 2001: 1). Meanwhile, according to M. Amin Syukur, Sufism is a branch of science in Islam which emerged later after Prophet Muhammad died. Scientifically, Sufism is the result of Islamic culture. The term tasawuf/ sufismwas not during Prophet Muhammad's period.At the time,there were titles such ascompanion, thenlater there weretabi'in, andtabi'ittabi'in. These termswere widely know in the 2nd or 3rd century Hijri (M. Amin Syukur, 2004: 3).

Because this term was not known at the time of Prophet Muhammad, many have questioned the origins of tasawuf / Sufism. For more details, the following is an explanation of the root word of Sufism. In general, tasawuf comes from

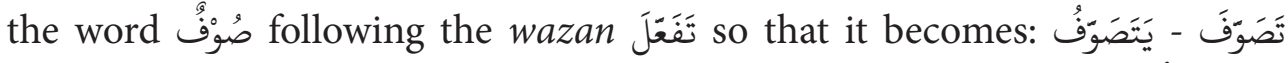
“تَصَوُفْ " تَصَوْفًا. Through the formation of words from this wazan, the term associated (Barmawie Umarie, 1966: 9).There are several words that are often associated with the term tasawuf. First, the word "shuff" (صوف), fleece, or wool. This word is used to show the simplicity of the Sufis that many appear wearing clothing in the form of coarse wool (similar to gunny sacks). Second, "Ibn al-Shauf" (الصوف إبن), refer tothose who lived before Prophet Muhammad, who dedicated their lives to serve God. They lived around the Ka'bah. Third, the word "Safa" (صفاء). This word takes the form of mabnimajhulwhich forms the wordmulhaq with the letter ya'nisbah, which denotes a name for people 
who are "clean" or "holy" (People who purify themselves before their Lord). Fourth, the word "shaf" (صف) which refers to people who always try to be in the front row during prayer.Fifth, the word "sovia" (سوفى), a term that equates its meaning with "wisdom" (حكمة), philosophy (Muhammad Sholikhin, 2009: 80-81). In light of the description, Sufi civilization can be interpreted as a civilization that departs from a trend established to respond to each change (innovative, creative and irreplaceable identity), as can be seen from the word "tashawwafa", always being in front (as in "shaf", departs from a pure heart (like the word "shafa"), always drawing closer to God (as in "ibnshauf”), always being cautious (as illustrated in "ahlshuffah" behavior ), and thinking / acting wisely, then producing thoughtfulworks that is useful to the general public (as exemplified by philosophers).

Furthermore, tracing the actions of Sufi scholars, it can be seen how dynamic their thought is. In almost the same time as fiqh and kalam, Sufism emerged through more universal concepts. Sufism comes with the concept of zuhud in the form of a mental attitude (not adrift in the sparkling worldly life, although still trying to benefit the world) $)^{3}$. The concept of zuhud later developed into khauf (fear of Allah) and raja' (submission only to Allah) according to Hasan al-Basri ${ }^{4}$, mahabbah (true love) according to Rabiah al-Adawiyah ${ }^{5}$, wahdatul wujud (unity of existence) according toIbnArabi ${ }^{6}$, WahdatusSyuhud(unity of testimony), love and passing awayaccording to IbnFaridh, wihdatulwujud (total submission to Allah) according to Al-Jilli, and so on. These various concepts later became a point of study material that is of interest to both Muslim and Orientalist scientists. Islamic civilization led by the "Sufis" is recognized by the world as "The Golden Age of Islam", as happened during the Abbasid dynasty",

${ }^{3}$ In the view of the Sufis, worldly passions are a source of human moral degradation. In order to avoid the temptations of lust, humans must be careful of the world and abandon worldly life and breaking away from material influences (Mukhtar Solihin \& Rosihon Anwar, 2002: 270).

${ }^{4}$ Hasan Basri was a Sufi Ulama who first appeared with the concept of Zuhud. Born in Medina in $642 \mathrm{AD}$ and died in $728 \mathrm{AD}$ (M. Amin Syukur, 2012: 30).

${ }^{5}$ According to al-Taftazani, in the second century Hijriyah, Rabi'ah al-Adawiyah presented zuhud in the form of mahabbatullah (hub Allah). One of the goals is to improve morale, amidst the degradation that occurred at that time (Abu al-Wafa' al-Ghanimi al-Taftazani, 1970: 80-81).

${ }^{6}$ Even with different terms, such as Ittihad and Hulul as Abu Yazid al-Bustami and Al-Hallaj, in essence the Sufis feel as if there is no distance between themselves and God (M. Hasyim Syamhudi, 2015: 277).

${ }^{7}$ The Abbasid Daula made a major contribution to the development of Islamic civilization, such as the compilation of hadith, state affairs, politics, law and economic subjects. Major figures were present there, such as: Al-Kindi, Al-Farabi, Ibn Sina, Ibn Bajah, Ibn Thufail, Ibn Rushd, Al-Abhari, etc., from the Philosophy field. Ibn Miskawaih, Ibn Sahal, Abu Bakkar Al-Razy, Ali bin Abbas, Ibn Sina, etc., from the field of Medicine; Ibn Baithar, Rashidun, Jubair bin Hayyan, etc., from the Pharmacy field. In addition, other fields also devel- 
where science and technology are the basis of development. Almost all fields were controlled by Muslims at that time, such as: politics, economics, social aspects, culture, to defense and security. Although in the end it was defeated by lust and anger.

Although the Abbasids collapsed, the scholars who had abilities in their respective fields could still exist until they were known in various parts of the world. The spread of Islam was carried out through wandering throughout the country, until reaching Nusantara (the Indonesian Archipelago). The wanderers were believed to be Sufis or students of famous Sufis. Since then, the people in Nusantara gained enlightenment and slowly but surely, became the largest Muslim country in the world. Hopefully, as stated by Nanat Fatah Nasir, "Indonesia, the New Synthesis of Civilization", the idea of Sufism becoming the starting point of the formation of civilizationis possible, given the condition of a pluralistic Indonesia.

\section{SUFI SCHOLARSHIP IN DEVELOPPING CIVILIZATION}

In the history of Islamic civilization, the term tasawuf/sufism appeared in the 3rd century Hijri. Even so, Sufism has basically been there since Prophet Muhammad was alive. The emergence of Sufism was a reaction from the scholars at that time, when they saw Muslims experiencing moral degradation. Scholars took a stand, by means of very simple dress, outside the mosque to get closer to God, teaching about eternal afterlife and reminding of the torment which is very painful for the wrongdoers (Syukur, 2012: 13). The collapse of the Abbasid dynasty in Baghdad devastated many. The scholars went wandering, trying to build anaspired new civilization. It was this odyssey which then brought them to the archipelago and spread the teachings of Islam which is rahmatanlilalamin. Their teaching books wereused in Nusantara. Their pattern of politeness and tolerancehaswon the hearts of many people, who were basically religious, in Nusantara and they became interested and determined to be Muslims. In the end, Islam grew rapidly in Nusantara, resulting in the countryhaving the largest Muslim population in the world. Therefore, it can be safely concluded that sufi civilization originated from thoughts about human morals. Sufism movement is a moral movement in response to inequality and irregularities that occurred in the early days of itsemergence. In the literature of Islamic civilization, Greek ethical philosophy and Persian moral thought were the keys to the success of a dynasty, but were

oped, such as astronomy, interpretation, Kalam, Sufism, and so forth. So, it is natural that Montgomery Watt, a historian, said that at that time during the first three centuries of Islam, it had changed the practice of initially primitive societies into cultured empires (Nanat Fatah Nasir, 2012: 107-108). 
more driven by Sufi teachings (Makdisi, 2015: 273).

In fact, the Islamic civilization that still stands firmly is Sufi civilization. Various forms of Islamic civilization that came to existence were in fact not built by concepts outside Sufism. Science was explored in such a way by Sufis, so that later it appeared to manifest into various forms of great works recognized by the world. Sufis always work on the basis of inspiration from their God, as a gift from their closeness to God. All of that is present by the grace of God, through zikir and a long time thought, until they are so close to God. Various forms of Islamic civilization that were written in history had the role of Sufis; the glory of the Umayyad Dynasty, the Abbasid Dynasty, and the Safavids in Persia (present day Iran). Islamic kingdoms in Nusantara all involved the Sufis in establishing a society order, so that they could stand firm and be respected by friends and opponents. Without the presence of Sufis, perhaps civilization was difficult to build.

The Safavid Kingdom in Persia, as an example is the kingdom that was founded by Shah Ismail I in $907 \mathrm{AH} / 1501 \mathrm{AD}$ in Tibriz, the capital city of the Kingdom of AlaqKonyulu which it conquered. This kingdom stood on the tradition of Sufism built by Safi al-Din 1301 AD in Ardabil. It is Junaid, a teacher (muryid) of the Safavid tareeqa who made political ijtihad by controlling the kingdom as a jihad in upholding the religion of Allah. The Safavids experienced a peak during the reign of Shah Abbas I (ruling from 1588 AD - 1642 AD), where the stability of government, economy, art, science, mysticism, and territory was built in such a way that it became the largest Islamic empire of its time (Abdillah, 2010: 30-42). The contribution of the Safavid Kingdom was enormous for the formation of the Islamic Republic of Iran in the future and for Muslims in general. According to Zulkifli Abdillah, the positive contributions include: first, laying the foundations for the life of the Shiite group in Iran which is still visible today; second, providing space for the growth of Islamic science, especially Philosophy, Fiqh and Sufism; third, the city of Isfahan as a physical contribution with high architecture and art (Abdillah, 2010: 47). Sufi civilization is created on the basis of the shahada, Laa Ilaaha illa Allah (tauhid). The journey of the Sufis is always in order to uphold the tauhid. They strive hard whenever and wherever for the sake of upholding Laa Ilaaha illa Allah.

Indonesia is another example of the works of the great Sufis. Islam came in the midst of people who had embraced strong faith and religion. However, Islam could be accepted well, without any significant rejection. The greatness and glory of this country can be traces back tosufism. Times have changed, although history repeats itself, as sunnatullah (the way Allah deals with His creation, so 
everything can be used as learning material). Therefore, many things can be learned from every event in the past, to be applied in the present. The ability to take lessons, innovate and think into the future, becomes a necessity on earth, so that wecan still exists and have identity. The optimism of Nanat Fatah Nasir indicates that Indonesia is a synthesis of Islamic civilization. Nasir perhaps saw the potential for Indonesia to become the center of world civilization. Indonesia is known as a melting pot of various elements of civilization. This country is inhabited by people who come from various ethnicities and nations; Arabs, Chinese, Indians, and so on. Natural resources and human resources are very sufficient to build a new civilization, which is different from world civilization which is built on only one group, such as the Arabs, Persians and Europeans.

\section{ISLAMIC CIVILIZATION AND SUFISM IN THE MELLENIAL ERA}

The needs of the older generation are to build a civilization for the next generations. Various efforts must be made, in order to create a great generation in the future. Now, the question iswhatis required to create a great generation? The answer is to return to Sufism, where many Sufis succeeded in building civilizations in the past. The Sufi concept, as offered by Sufis in general, can be used as an example. Aal-Ghazaliwas able to reconcile the Sharia conflict with Hakikat, then what he exemplified is the science of conflict resolution. Most Sufis left ustheir works. This means that we should continue to work. They were fighters for freedom against the invaders that set an example for fighting in the path of Allah. The Shiddiqiyah congregation in Jombang managed to build a factoryand whichgives us an example of economic development. The Sufis were able to build educational institutions from the elementary to the tertiary level whichexeplifiescreation of civilization. The Sufis have never stopped fighting for the creation of civilization and the greatness of the generations to come.

Indonesia as a large country with the largest population of Muslims in the world, with various tribes, customs, cultures and religions, is certainly prone to disruptions. Fortunately, since the beginning, this country has been blessed with a mutual agreement called Pancasila. Had Pancasila not proposed, it would have been difficult to unite this nation, let alone to build a great one. Recently, a new term has emerged in the world of academics, which is "virally infecting" every theme of scientific activities. The term disruptive is widely used to describe a chaotic state of a nation. The word nation here is a global term that represents the whole of a group of people from generation to generation. In the past, disruption was similar to degradation. Then what 
exactly is disruption? In English, disruption means disturbance or disorder. Disruptive means causing disruptionor being divisive (John Echol \& Hassan Sadily, 1995: 189). So it is natural that this earahas been referred to asbeing disruptive, an era full of acts of chaos, disruption and fragmentation.

Efforts to divide the people and the nation, from the beginning of the Unitary State of the Republic of Indonesia (NKRI) have never subsided by both internal and external parties. As a result of the influence from various sides, many people were triggered to take disruptive-political actions. To gain influence or benefit economically, they are willing to 'trade' their own people, by creating political chaos in this safe, peaceful and prosperous country. It is widely known that 2018 is a political year for Indonesia. Departing from the experience of 2014, the political arena at the elite level brought pain and damaged the mentality of the nation's children. The emergence of various "cyber crime", arguing on social media, disseminating hoaxes, and efforts to create riots, are part of disruption in our society. This year, the political arena will be held again, so being aware of disruption in society is a must!

Tracing back into the past for a moment, basically Sufism is a form of disruption of the established regime in which it first appeared in the 3rd century. Through the search of history, the datashow that Sufism was born due to injustice and chaos of the Islamic Caliphate led by Yazid (BanuUmmayyad 630-700 AD). The word disruption here is interpreted as an effort to create new order to compete with an established regime. When looking at the deviations of the Islamic Caliphate principles at the time, Sufis rose with different trends, wearing simple clothes in the capacity of those who should be able to wear luxury and have exclusive facilities. The efforts they made were aimed at providing learning as well as protesting against the Caliph regarding their wrongdoings.

The term disruptive in this context is interpreted as negativity for the authorities who tried to establish a system, and can also be interpreted as positivity in an effort to improve the situation. In this way, the Sufis succeeded in returning the principles of the Caliphate as applied by the Messenger of Allah and the Companions, so that a highly respected caliph was born who had a strong Sufi principle, namely the Caliph Umar ibn Abdul Aziz. The presence of Caliph Umar ibn Abdul Aziz, gave a new dimension to the Islamic Caliphate which was in accordance with the Islamic Sharia.

Changes in the tendency of society from time to time were closely followed by the Sufis so as to continue to be creative in strengthening their existence among Muslims and the world community. Fazlurrahman in his book, "Islam", provides information that Sufism through its tareqa has always metamorphosed against 
change. Sufism, which at first did not think about economic issues, turned into business institutions that deserved to be taken into account. Not to mention if seen from the history of the arrival and spread of Islam in Indonesia, it is clear that the Sufis paid special attention to the traditions of the local people during propagation of Islam. The transformation of culture from local culture to Islamic culture became the mainstay of the Sufi propaganda pattern. What was done by the Sufis, turned out to produce brilliant results, with the spread of Islam in the archipelago without any significant rejection from locals who from the beginning had been religious? The earlier description illustrates that Sufism in fact always tries to adjust themselves in every situation, without changingits original purpose, namely to make Muslims close to their God. In fact, Sufism always succeeded in completing its mission. One can see the proof as Sufism is still growing now in Nusantara.

\section{BUILDING MENTAL AND SPIRITUAL FOUNDATION}

The interesting phenomenon in the current millennial generation is the hijrah. Ithas emerged since the 2000s, as the antithesis of the phenomenonof glamorous young generation. The phenomenon of hijrah, according to Abdul Hair, is caused by two factors, namely: first, the loosening of the New Order's government policy towards Islamic identity; and, second, because of the sponsorship of the world of industry which contributed to its increase ${ }^{8}$. According to Husnul Athia, the millennial generation who did the hijrahwas identical with several changes, including how women dress (who initially wore jeans and tight clothes, turned into more Islamic with long and wide veils covering the chest and loose clothes, some even wearing niqab). While men tend to grow their beards and shorten their pants above the ankle.The content they share on social media also tends to be similar, namely short lectures by well-known religious teachers such as Ustadz Adi Hidayat, Ustaz Khalid Basalamah, Ustadz Hanan Attaqi and Ustadz Abdus Somad?

The millennial generation is very interesting to discuss, considering many aspectssuch as education, norms, social awareness, mental conditions, and dependence on the use of technology. There is quite a lot of research that has been carried out related to the topic, one of which was published by Heru Dwi Wahana. Heru Dwi Wahana's research in 2014 at Cijantung State High School 39 East Jakarta, with a sample of as many as 186 people, showed remarkable results from the influence of Cultural Values with the Resilience of

8 (Abdul Hair, on: https://news.detik.com/kolom/d-3840983/ fenomena-hijrah-di-kalangan-anak-muda, accessed in February 13,2018).

${ }^{9}$ (Husnul Athia, on: https://alif.id/read/husnul-athiya/tren-berhijrah-generasi-milenial-b206839p/, accessed in February 15, 2018). 
Millennial Generation Individuals, based on the statistics, cultural values that appeared in their surroundings (school) produce high individual resilience. The characteristics of the millennial generation, as compiled from the results of these studies are as follows: 1) Making technology a lifestyle; 2) sheltered generation; 3) born of educated parents; 4) multi-talented, multi-langual, expressive and explorative; 5) always confident and optimistic; 6) simplicity, and everything being instant, accomplishment must be achieved; 7) work and study more interactively through teamwork, collaboration and thought groups, independent and structured in the use of technology, communication gadgets, preferring visual instruction in accessing the internet,; 8) Instant Communication, real time, Network Development; 9) more open to various access of information; 10) tendency to be more permissive to diversity; 11) carefree about privacy and willing to share intimate details about themselves with strangers byposting online status a daily activity; 12) having a view that family is a very important pillar of their lives (Heru Dwi Wahana, 2015: 2021).

Self-resilience is a mental issue for the millennial generation. The twelve points above illustrate the mental conditions of the millennial generation that must be resolved, or as challenges that must be answered by Sufism in founding a civilization. One of the main functions of Sufism is to build a resilient human mentality, so as to survive invarious situations and conditions around it, while making changes in a better direction. Basically, digital technology can be taken from the origin of the concept of the harmony of the universe regarding the concept of life and death. This concept can be seen from the shahada: Laa (Zero) Ilaaha (One) Illa (Zero) Allah (one). In that sentence, there are numbers: 0.1.0.1. The more LaaIlaahaIlla Allahis recited, the more numbers will be created. In the concept of digital technology, basically this technology is formed from binary numbers Zero (Off) and One (On). Therefore, the more On and Off the technology, the more harmonious motion that occurs in technological devices. If only On and Off can be used as a lifestyle, then one will get closer to God (Elmansyah Al-Haramain, 2014: 158-159).

Therefore, the millennial generation has the potential to be very close to God, because "it has become their daily lifestyle". However, they need a comprehensive explanation of the existence of God in the technology they are using. The more they realize the existence of God, the easier the creation of Sufism civilization will be. Considering that, LaaIaahaIlla Allah is the main zikir of the Sufis, whenever and wherever they are. This zikir, in the QadiriyahandNaqshabandiyahtareeqa is called zikirnafy (annihilation) istbat (determination). On the other hand, the mentality and spirituality of the Sufis 
have been shown in such a way by Fazlurrahman in his book, Islam (1979). As elaborated by Hermansyah (2013) the term, "Neo-Sufism" was known in the modern era. In his conclusion, Hermansyah mentioned that Sufis can answer challenges, with concerns about environmental issues, social ethics, and the future of humanity. The mainstay of the Sufis includes the power of empirical science and mystical spiritual awareness (Hermansyah, 2013: 119).

Thus, mentality and spirituality can be developed simultaneously by strengthening zikir in the millennial generation. There is a lot of evidence from research that shows that zikir (in the broad sense: all forms of ritual worship in Islam) can solve the problem of human life. Research by Moh. Soleh of UIN Sunan Ampel Surabaya, for example, shows that Tahajud Prayer can cure cancer. Mwanwhile a study conducted bydrSugiran, a surgeon, shows that the prayer movement has physical and mental health effects. Prof. M. Amin Syukurs of UIN Walisongo Semarang had experience that gave evidence that zikir curedhis cancer, and many more, including Duha Prayer and charitythat promises financial sufficiency ${ }^{10}$. The description is basically the daily activities of the Sufis in a larger portion than the others. This is also what strengthens the mentality of the Sufis, both in dealing with world problems and the afterlife, so as to be able to create their own civilization in Islamic history.

\section{CONCLUSION}

I have come to understand that the enforcement related to the issu of Sufism and its religious values and activities may create an alternative of strategies in dealing with the current mellineal generation in a more acceptable Islamic civilization in Indonesia, which will draw the world's attention. Mental and spiritual strengthening is the key to the success of the millennial generation. Some important points are concluded by this work. First, the emergence of the Sufis in the 3rd century Hijri was part of the response to changes. This means that the current situation and conditions of the millennial community await the reappearance of Sufis who actively play a role in the community, so that they can create better changes in the future. Second, in dealing with changes, the Sufisshould return to the spirituality. Things are changing drastically, which requiresa return to the spirituality. Otherwise, there will be a lot of people trapped in emptiness, which will have fatal consequences for future

${ }^{10}$ For more detail, read: Moh. Sholeh, Terapi Shalat Tahajjud: Menyembuhkan Berbagai Penyakit (Jakarta: Penerbit Noura, 2012); Sugiran, Mukjizat Gerakan Shalat: Penelitian Dokter Ahli Bedah dalam Pencegahan dan Penyembuhan Penyakit (Jakarta: Qultum Media, 2012); M. Amin Syukur, Zikir Menyembuhkan Kankerku: Pengalaman Kesembuhan Seorang Penderita Kanker Ganas yang telah Divonis Memiliki Kesempatan Hidup Hanya Tiga Bulan (Bandung: PT Mizan Publika, 2007); Yusuf Mansur, Merubah Keadaan Hidup dengan Shalat dan Sedekah: The Amazing Power of Shalat and Giving (Jakarta: Zikrul Hakim, 2011), etc. 
development. Third, the strong mentality of Sufis can be used as an example in building civilization. Fourth, the attitude, examples and tolerance of the Sufis can be developed in Indonesia, which has been proven to be able to spread the face of peaceful Islam in society. Fifth, the efforts of the Sufis in developing science, philosophy, art, religion, etc., can be used as examples in building civilization.

\section{BIBLIOGRAPHY}

Abdillah, Z., (2010). Kepingan-Kepingan Sejarah Umat Islam. Pontianak: STAIN Pontianak Press.

Abdul, H., "FenomenaHijrah di KalanganAnakMuda", (Peneliti Kajian Budaya Pop, Media danKomunikasi), Tuesday, 30 January 2018, on: https://news.detik.com/kolom/d-3840983/fenomena-hijrah-di-kalangan-anak -muda.

Al-Haramain, E., (2014). Sejarah Peradaban Islam dalam Tasawuf: Sebuah Pemaparan Awal. Pontianak: STAIN Pontianak Press.

Al-Taftazani, A. A., (1970). Al-MadkhalIlaTasawwuf al-Islami. Mesir: Dar al-Tsaqafah.

Echol, J. \& Sadily, H., (1995). Kamus Bahasa Inggris - Indonesia. Jakarta: Gramedia.

Elmansyah. (2016). Dakwah Sufistik di Era Digital, Al-Hikmah: JurnalDakwah. 10 (1). [p. 56-74].

Hermansyah. (2013). "Neo Sufisme: SejarahdanProspeknya", Khatulistiwa: Journal of Islamic Studies. 3 (2). [p. 113-120].

Hornby, A. S. (1995). Oxrord Advanced Learner's Dictionary of Current English International Studen's New Edition. New York: Oxford University Press.

Husnul, A., (2018). Trend "Berhijrah" GenerasiMilenial, Thrusday 1 February 2018, on: https://alif.id/read/husnul-athiya/tren-berhijrah-generasi-milenialb206839p/.

Makdisi, G. A., (2015). Citra Humanisme Islam: Panorama Kebangkitan Intelektual dan Budaya Islam dan Pengaruhnya terhadap Renaisans Barat. Jakarta: Serambi Ilmu Semesta.

Mansur, Y., (2011). Merubah Keadaan Hidup dengan Shalat dan Sedekah: The Amazing Power of Shalat and Giving. Jakarta: Zikrul Hakim.

Munawwir, A. W., (1984). Kamus Al-Munawwir: Arab-Indonesia Terlengkap 
Edisi Kedua. Surabaya: Penerbit Pustaka Progressif.

Nasir, N. F., (2012). The Next Civilization: Menggagas Indonesia sebagai Puncak Peradaban Dunia. Jakarta: Media Maxima.

Palfrey, J. \& Gasser, U., (2008). Born Digital: Understanding the First Generation of Digital Natives. New York: Basic Books, a Member of Perseus Books Group.

Penyusun, T., (2008). Kamus Bahasa Indonesia. Jakarta: Pusat Bahasa.

Shermon, G., (2017). Digital Cultures: Age of the Intellect (Lulu.com: Lulu Publishing Services.

Sholeh, M., (2012). Terapi Shalat Tahajjud: Menyembuhkan Berbagai Penyakit. Jakarta: Penerbit Noura.

Sholikhin, M., (2009). 17 Jalan Menggapai Mahkota Sufi Syeikh 'Abdul Qadir Al-Jailani: Intisari Kitab Karta Al-Jailani, Al-Fath al-Rabbany, Sirr al-Asrar, Al-Futuh al-Ghayb dan Al-Ghunyah Li Thalibi Thariq alHaqq. Yogyakarta: Mutiara Media.

Solihin, M. \& Anwar, R., (2002). Kamus Tasawuf. Bandung: Pustaka Rosdakarya.

Sugiran, (2012)., Mukjizat Gerakan Shalat: Penelitian Dokter Ahli Bedah dalam Pencegahan dan Penyembuhan Penyakit. Jakarta: Qultum Media.

Syamhudi, M. H., (2015). Akhlak - Tasawuf dalam Konstruksi Piramida Ilmu Islam. Malang: Madani Media.

Syukur, M. A., (2012). Menggugat Tasawuf: Sufisme dan Tanggung Jawab Sosial Abad 21. Yogyakarta: Pustaka Pelajar.

-. (2004). Tasawuf Sosial. Yogyakarta: Pustaka Pelajar.

(2007). Zikir Menyembuhkan Kankerku: Pengalaman Kesembuhan Seorang Penderita Kanker Ganas yang telah Divonis Memiliki Kesempatan Hidup Hanya Tiga Bulan. Bandung: PT Mizan Publika.

Umarie, B., (1966). Sistematika Tasawuf. Sala: Penerbit Siti Syamsiyah.

Wahana, H. D. (2015). "Pengaruh Nilai-Nilai Budaya Generasi Millenial dan Budaya Sekolah terhadap Ketahan Individu: Studi di SMA Negeri 39 Cijantung Jakarta”, JurnalKetahananNasional. XXI (1). [p. 14-22].

Yatim, B., (2001). Sejarah Peradaban Islam: Dirasah Islamiyah II. Jakarta: Raja Grafindo Persada. 